\section{Occurrence and Location of Endophytic Bacteria in Garden and Wild Strawberry}

\author{
S. Kukkurainen, A. Leino, S. Vähämiko, H.R. Kärkkäinen, K. Ahanen, \\ and S. Sorvari ${ }^{1}$ \\ MTT Agrifood Research Finland, Horticulture, Toivonlinnantie 518, FIN-21500 \\ Piikkiö, Finland
}

R. Rugienius

Lithuanian Institute of Horticulture, Babtai, LT-4335, Kaunas Distr., Lithuania

\section{O. Toldi}

Agricultural Biotechnology Center, H-2100, Gödöllö, Szent-Györgyi Albert út 4, P.O. Box 411, Hungary

Additional index words. ERIC-PCR, in situ hybridization, micropropagation, plant colonization, Fragaria xananassa Duch., Fragaria vesca L.

\begin{abstract}
The occurrence of bacteria in different tissues was studied using field-grown strawberries, in vitro-grown strawberries, wild strawberries, and aseptically germinated strawberry seedlings. Strawberry has a number of endophytic bacteria in its the internal tissue, most of which appear to be nonpathogenic. In the in vitro-grown strawberries, all identified isolates were in the genus Pantoea. In field-grown garden and wild strawberries the most common genera were Pantoea and Pseudomonas. Location of eubacterial inhabitants within strawberry tissue sections was studied by in situ hybridization. Bacteria were detected in flower stalks, leaf stalks, leaves, stolons, berries and aseptically germinated seedlings. The existence of bacteria in seeds and seedlings suggests that bacteria are able to move up to the generative tissue and, ultimately, to the next generation, forming a symbiosis-like chain of plant-bacteria coexistence.
\end{abstract}

Plants are not microbial vacuums. Intercellular spaces, vascular systems and even single cells are inhabited by several kinds of bacteria and other microbes. The asymptomatic existence of endophytic bacteria has been reported for many species, e.g., strawberry (Berg et al., 2000; Ferguson et al., 2000; Guinebretiere et al., 1999, Tanprasert and Reed, 1997), tomato (Samishetal., 1961), pea (Elvira-Recuenco and van Vuurde, 2000), potato (Sturz et al., 1999), cucumber (Mahaffee and Kloepper, 1997), cotton (Chen et al., 1995), and globe artichoke (Peñalver et al., 1994). Both nonpathogenic and pathogenic bacteria can be present, causing no apparent effect on the plant (Bacon and Hinton, 1997). Endophytic bacteria have also been reported to promote plant growth and development (Frommel et al., 1991; Nejad and Johnson, 2000; Pillay and Nowak, 1997; Sturzet al., 1998) through production of phytohormones (Frommel et al., 1991; Holland, 1997), through induction of hormone synthesis by plants (Lazarovits and Nowak, 1997), or through fixation of atmospheric nitrogen (Barraquio et al., 1997). Endophytes may suppress disease by inducing systemic resistance in plants (Cameron et al., 1994), or by producing antibiotic secondary metabolites (Wright et al., 2001), fungal cell wall-degrading enzymes (Pleban et al., 1997) or $\mathrm{Fe}^{3+}$-chelating siderophores (Davison, 1988).

The aim of this study was to find out which

Received for publication 7 May 2003. Accepted for publication 24 Jan. 2004.

${ }^{1}$ To whom reprint requests should be sent; e-mail seppo.sorvari@mtt.fi. free Murashige and Skoog (1962) medium of half strength, without casein hydrolysate. Leaf stalks of the seedlings were used for the in situ hybridization.

Isolation of bacteria. Leaf stalks, leaves, roots, flower stalks, flowers, berries, seeds and internodal sections of stolons of field-grown garden strawberry (Fragaria $\times$ ananassa Duch.) and wild strawberry (Fragaria vesca L.) were washed $1 \mathrm{~min}$ in running tap water and $1 \mathrm{~min}$ in running deionized water. The material was surface sterilized $2 \mathrm{~min}$ in 50\% EtOH, 2-6 min (depending on the plant tissue) in $5.25 \%$ sodium hypochlorite, with $1 \%$ Triton X-100(BDHLaboratory Supplies, Poole, U.K.), 2 min in $50 \% \mathrm{EtOH}$, and finally rinsed $3 \times 3 \mathrm{~min}$ in sterile distilled water. Surface sterilized leaves, stalks, roots and stolons were cut into 4- to 5-mm pieces, berries were peeled, pistils remained uncut, and stamens either cut in half or left uncut.

Surface sterility was tested by imprinting the pieces on agar plates. After 30 minutes, the pieces were removed and transferred onto agar plates of the same type and incubated at $28^{\circ} \mathrm{C}$ up to 3 weeks. For surface sterility check and bacterial culture, the following media were used: tryptic soy broth (Sigma Co., St. Louis, Mo.) with $1.7 \%$ agar (Sigma type A), potato dextrose broth (Sigma) with $1.7 \%$ agar, malt extract broth (Sigma) with $1.7 \%$ agar, nutrient peptone medium $\left[10 \mathrm{~g} \cdot \mathrm{L}^{-1}\right.$ glucose, $5 \mathrm{~g} \cdot \mathrm{L}^{-1}$ malt extract, $1 \mathrm{~g} \cdot \mathrm{L}^{-1}$ yeast extract, $8 \mathrm{~g} \cdot \mathrm{L}^{-1}$ nutrient broth (Sigma), $1 \mathrm{~g} \cdot \mathrm{L}^{-1}$ Bacto peptone (Difco Laboratories Inc., Detroit, Mich.), $20 \mathrm{~g} \cdot \mathrm{L}^{-1}$ agar, $\mathrm{pH}$ 6.8 to 7.0 ], cornmeal-malt extract agar (Bacon et al., 1977), SC medium (Deutsche Sammlung von Mikroorganismen und Zellkulturen $\mathrm{GmbH}$, Braunschweig, Germany, DSMZ medium 751) and M9 medium (DSMZ medium 382). Bacterial growth associated with the plant pieces was purified by repeated plating on agar medium. If sterility check was positive, the culture was discarded. Plant parts from the in vitro cultures of 'Jonsok', 'Pocahontas', 'Hella', and 'Bounty' were sterility checked, although they were not surface disinfected.

Bacterial cultures from berries and wetted seeds were established by crushing the plant material using mortar and pestle with phosphatebuffered saline solution (PBS: $8.0 \mathrm{~g} \cdot \mathrm{L}^{-1} \mathrm{NaCl}$, $0.2 \mathrm{~g} \cdot \mathrm{L}^{-1} \mathrm{KCl}, 1.1 \mathrm{~g} \cdot \mathrm{L}^{-1} \mathrm{Na}_{2} \mathrm{HPO}_{4}$, and $0.2 \mathrm{~g} \cdot \mathrm{L}^{-1}$ $\mathrm{KH}_{2} \mathrm{PO}_{4}, \mathrm{pH}$ 7.4), and plating the slurry. Apart from small plant pieces, extraction of vascular fluid from 10- to 15-cm-long stalks and stolons was used for isolation of bacteria. Surface sterilized stalks and stolons were placed into plastic tubes filled with sterile distilled water through an aseptically cut hole in the cap. A disposable plastic pipette was aseptically sealed with the aid of Parafilm to the end of the stalk or stolon and pressed in order to obtain a vacuum in the pipette. After $12 \mathrm{~h}$, the fluid conveyed to the pipette was spread onto plates. Alternatively, fluid was extracted from stalks and stolons by centrifugation (Hallmann et al., 1997).

Identification of bacteria. Isolates were Gram stained using the Gram stain kit (Sigma HT90-A). Gram-negative rod-shaped bacteria were tested using the API 20 E test system (bioMérieux sa, Marcy-l'Etoile, France). The seven-digitAPI profile was complemented with 
additional tests for nitrate and nitrite reduction, motility and growth on McConkey broth with $1.7 \%$ agar (Sigma). In a few cases, a closer identification of pseudomonads was made by observing fluorescent pigment production on King agar B (Fluka Chemie AG, Buchs, Switzerland, according to King et al., 1954). Identification of some Gram-negative and Gram-positive isolates was confirmed through gas-liquid chromatography, in combination with API 20 NE, API 20 E or ID 32 STAPH plates (bioMérieux), at Y-Lab, University of Turku, Finland.

Bacterial lysates were prepared from broth cultures according to Lu et al. (2000). PCR with ERIC1R [5'-ATGTAAGCTCCTGGGGATTCAC-3'] and ERIC2 [5'-AAGTAAGTGACTGGGGTGAGCG-3'] primers (Versalovic et al., 1991) was carried out using PCR Master Mix (Cat. no. M7502, Promega Corporation, Madison, Wis.) and a PTC-100 programmable thermal controller(MJ Research, Inc., Watertown, Mass.). Primers were purchased from the DNASynthesis and Sequencing Laboratory, University of Helsinki, Finland. Strains from the microbial culture collections HAMBI (University of Helsinki, Finland) and DSMZ were used as standards.

In situ hybridization. Endophytic bacteria was located using in situ hybridization with the digoxigenin 3'-labelled EUB338 (5'-GCTGCCTCCCGTAGGAGT-3') probe, which is according to Amann et al. (1992) complementary to the eubacterial $16 \mathrm{~S}$ rRNA sequence.
The EUB338 sequence was obtained from the DNA Synthesis and Sequencing Laboratory of the University of Helsinki and the DIG Oligonucleotide 3'-End Labeling Kit (Cat. no. 1362 372) from Roche Diagnostics $\mathrm{GmbH}$, Mannheim, Germany.

Plant material was washed and surface-sterilized, fixed according to Pirttilä et al. (2000), and embedded (Ruzin, 1999) in paraffin (Cat. no. 1.07164, Merck KgaA, Darmstadt, Germany). Sections of 10 to $12 \mu \mathrm{m}$ thick were attached to Bind-Silane-coated (Promega Q421A) glass slides and baked overnight at $+42^{\circ} \mathrm{C}$. The sections were deparaffinized, rehydrated (Rolighed and Lindeberg, 1996), permeabilized $10 \mathrm{~min}$ with $30 \mu \mathrm{g} \cdot \mathrm{mL}^{-1}$ Proteinase K (Sigma P6556) in TES buffer [ $50 \mathrm{~mm}$ Tris-HCl (pH 7.4), $10 \mathrm{~mm}$ EDTA, $10 \mathrm{~mm} \mathrm{NaCl}$ ], and fixed in $0.4 \%$ formaldehyde (Rolighed and Lindeberg, 1996).

Slides were prehybridized for $1 \mathrm{~h}$ at $38^{\circ} \mathrm{C}$ in hybridization standard buffer with formamide, according to Eisel et al. (2000), where formamide concentration was modified to $20 \%$. The probe was diluted with hybridization buffer up to the concentration of $0.35 \mathrm{ng} \cdot \mu \mathrm{L}^{-1}$, and added to the slides in volumes of $100 \mu \mathrm{L} /$ slide. The slides were placed on a heating tray at 80 ${ }^{\circ} \mathrm{C}$ for $10 \mathrm{~min}$ to denature the DNA, and then cooled on ice. The probe was hybridized to the sections overnight at $38^{\circ} \mathrm{C}$ in a humid chamber. The unhybridized probe was removed from the slides by washing $2 \times 5$ min in $2 \times \operatorname{SSC}(20 \times$ SSC: $3 \mathrm{M} \mathrm{NaCl}, 0.3 \mathrm{~m}$ sodium citrate, $\mathrm{pH} 7.0$ ), $0.1 \%$ sodium dodecyl sulphate (SDS) at RT, and
$2 \times 15$ min in $0.5 \times \mathrm{SSC}, 0.1 \% \mathrm{SDS}$ at $38^{\circ} \mathrm{C}$, and the slides were cooled to RT. Anegative control was prepared by applying hybridization buffer without a probe on one slide. Hybrids were visualized with the DIGNucleicAcid Detection Kit (Roche Cat. no. 1175 041) and slides were mounted in Aquamount (BDH).

\section{Results}

Microbial endophytes were found and isolated from field-grown garden strawberry, in vitro-grown garden strawberry, and wild strawberry. In aseptically germinated seedlings, however, the existence of bacteria could be shown by in situ hybridization only.

The distribution of bacteria in the different plant types was similar(Table 1). Gram-negative rods were the most predominant group among the endophytic isolates, ranging from $75 \%$ to $93 \%$. The proportion of Gram-positive rods ranged from $0 \%$ to $21 \%$, and Gram-positive cocci from $1 \%$ to $7 \%$.

Pantoea spp. and Pseudomonas fluorescens were the most frequently isolated and identified bacteria in the different strawberry types (Table 2). Pantoea was present in all strawberry types, whereas pseudomonads were not discovered in the in vitro-grown or nonmicropropagated field-grown garden strawberry.

A summary of bacterial isolates from different plant tissues is presented in Table 3. Bacteria identified as Pantoea spp. were discovered from all vegetative tissues. Pseudomonads,

Table 1. Distribution of endophytic bacteria in different strawberry types, according to their Gram staining ability and morphology.

\begin{tabular}{|c|c|c|c|c|c|}
\hline & $\begin{array}{c}\text { Garden type, } \\
\text { field-grown, } \\
\text { not micropropagated }\end{array}$ & $\begin{array}{c}\text { Garden type, } \\
\text { field-grown, } \\
\text { micropropagated }\end{array}$ & $\begin{array}{l}\text { Garden type, } \\
\text { in vitro-grown }\end{array}$ & Wild type & $\begin{array}{l}\text { Wild type, } \\
\text { field-grown }\end{array}$ \\
\hline Gram-negative rods & $84 \%\left(70^{z}\right)$ & $90 \%(147)$ & $92 \%(33)$ & $93 \%(26)$ & $75 \%(18)$ \\
\hline Gram-positive rods & $11 \%(9)$ & $9 \%(15)$ & $6 \%(2)$ & $0 \%(0)$ & $21 \%(5)$ \\
\hline Total of bacterial isolates & $100 \%(83)$ & $100 \%(164)$ & $100 \%(36)$ & $100 \%(28)$ & $100 \%(24)$ \\
\hline
\end{tabular}

${ }^{2}$ The numbers of isolates are given next to the percentages in parentheses.

Table 2. Distribution of endophytic bacterial taxa and groups in different strawberry types. The frequencies of bacteria are given as absolute numbers and percentages of the total number of bacterial isolates (in parentheses).

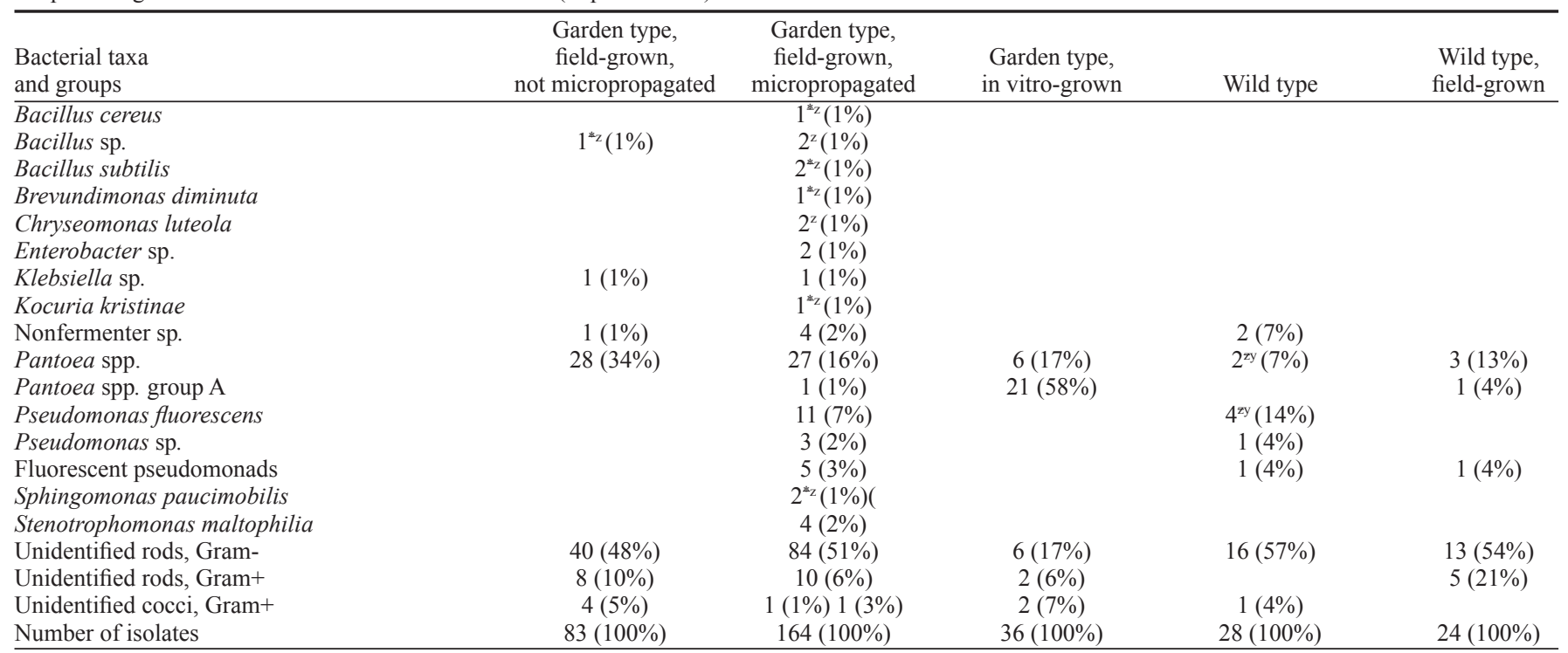

Identified by Y-Lab, University of Turku.

${ }^{y}$ Some of the isolates were identified by Y-Lab, University of Turku. 
Table 3. Endophytic bacteria isolated from different plant types grouped by identification and plant tissue origin; A = garden strawberries 'Bounty', 'Jonsok', 'Korona' and 'Kent'; B = garden strawberries 'Hella', 'Pocahontas', and 'Ydun'; I = in vitro garden strawberries 'Bounty', 'Jonsok', 'Pocahontas', and 'Hella'; V = wild strawberry from the field; and $\mathrm{W}=$ wild strawberry from the edge of the forest.

\begin{tabular}{|c|c|c|c|c|c|c|c|c|}
\hline \multirow[b]{2}{*}{ Bacterial taxa and groups } & \multicolumn{8}{|c|}{ Plant tissue } \\
\hline & Root & Stolon & Leaf stalk & Leaf & Flower stalk & Flower & Berry & Seed \\
\hline Bacillus cereus & $\mathrm{A}^{* \mathrm{z}}$ & & & & & & & \\
\hline Bacillus sp. & $\mathrm{A}^{\mathrm{z} *} \mathrm{~B}^{\mathrm{z} *}$ & & & & & & & \\
\hline Bacillus subtilis & $\mathrm{A}^{\mathrm{z} *}$ & & & & & & & \\
\hline Brevundimonas diminuta & & & $\mathrm{A}^{\mathrm{z*}}$ & & & & & \\
\hline Chryseomonas luteola & $\mathrm{A}^{\mathrm{z*}}$ & & & & A & & & \\
\hline Enterobacter sp. & & & & & & & A & \\
\hline Klebsiella sp. & & B & & & & & A & \\
\hline Kocuria kristinae & & & $\mathrm{A}^{\mathrm{z} *}$ & & & & & \\
\hline Nonfermenter sp. & & A & ABW & & A & & & \\
\hline Pantoea spp. & A & $\mathrm{BI}$ & ABIVW & $\mathrm{BIW}^{\mathrm{z} *}$ & $\mathrm{AB}$ & A & $\mathrm{AB}$ & \\
\hline Pantoea spp. group A & A & $\mathrm{I}$ & I & $\mathrm{IV}^{* * \mathrm{y}}$ & & & & \\
\hline Pseudomonas fluorescens & $\mathrm{A}^{\mathrm{z} * \mathrm{~W}}$ & A & $\mathrm{AW}^{\mathrm{z} *}$ & W & $\mathrm{A}^{\mathrm{z} *}$ & $\mathrm{~W}^{\mathrm{z} *}$ & & $\mathrm{~A}^{\mathrm{z} *}$ \\
\hline Pseudomonas sp. & & W & & & $\mathrm{A}$ & A & & $\mathrm{A}$ \\
\hline Fluorescent pseudomonads & & $\mathrm{A}$ & A & AVW & A & & & \\
\hline Sphingomonas paucimobilis & $\mathrm{A}^{\mathrm{z} *}$ & $\mathrm{~A}^{\mathrm{z} *}$ & & & & & & \\
\hline Stenotrophomonas maltophilia & & A & & & A & & & \\
\hline Unidentified rods, Gram- & A & ABIW & ABIVW & ABIVW & ABW & AW & ABW & A \\
\hline Unidentified rods, Gram+ & A & IV & BV & A & B & & $\mathrm{AB}$ & A \\
\hline Unidentified cocci, Gram+ & & & $\mathrm{AB}$ & BIV & W & & & \\
\hline
\end{tabular}

Identified by Y-Lab, University of Turku.

${ }^{y}$ A mixture of leaves and stalks was used for isolation of bacteria.

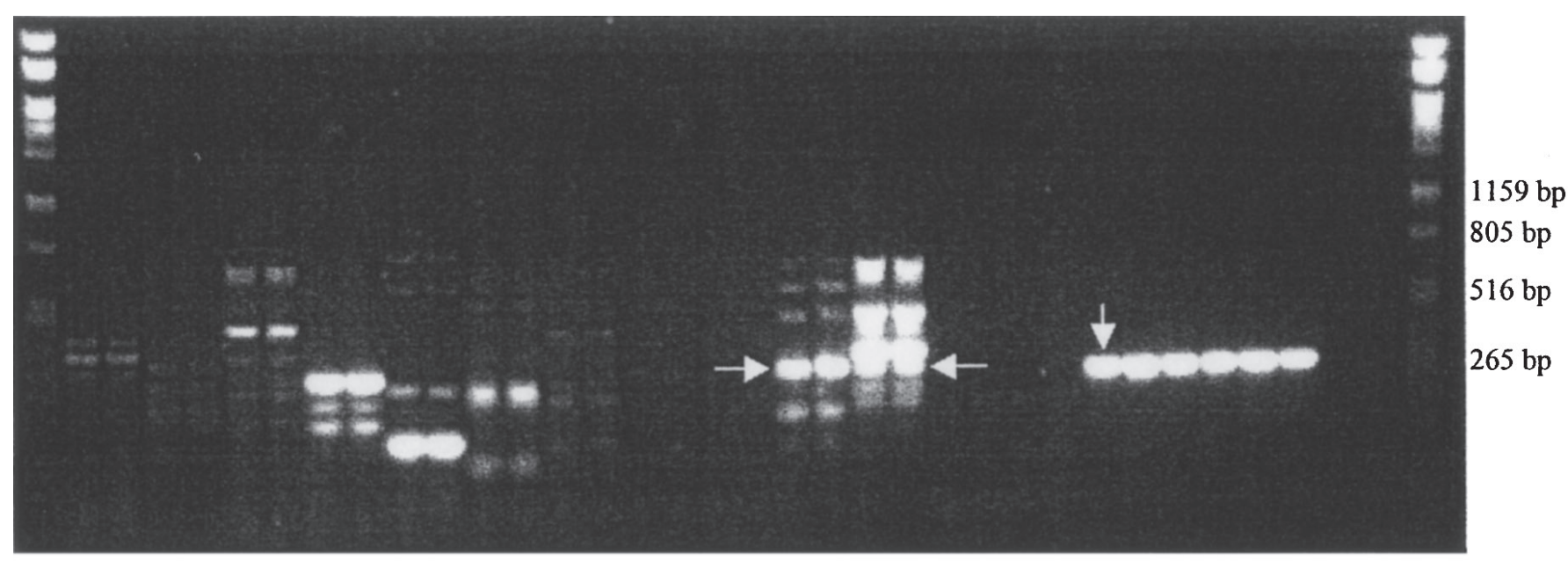

M la,b 2a,b 3a,b 4a,b 5a,b 6a,b 7a,b 8a,b 9a,b 10a,b 11a,b 12a,b 13a,b 14a,b 15a,b 16a,b 17a,b M

Fig. 1. Fragment patterns created in ERIC-PCR. (M) molecular weight marker (PstI-digested $\lambda$-DNA, Promega), (1a,b) Pseudomonas aeruginosa HAMBI 25, (2a,b) P. chlororaphis HAMBI 1977, (3a,b) P. fragi HAMBI 28, (4a,b) P. fluorescens HAMBI 2167, (5a,b) P. putida HAMBI 17, (6a,b) P. syringae pv. syringae HAMBI 1436, (7a,b) P. syringae pv. phaseolicola HAMBI 1435, (8a,b) Ralstonia pickettii HAMBI 2158, (9a,b) Xanthomonas campestris HAMBI 104, (10a,b) Pantoea agglomerans HAMBI 1899, (11a,b) Erwinia carotovora HAMBI 1429, (12a,b) Burkholderia cepacia HAMBI 1976, (13a,b) Burkholderia gladioli HAMBI 2157, and Pantoea isolates (14a,b) K57, (15a,b) K64, (16a,b) K61a, and (17a,b) negative control lacking template DNA are shown.

Pseudomonas fluorescens in particular, were also found distributed in all plant parts, except berries. Bacillus was detected only in roots, whereas Chryseomonas and Sphingomonas were found inhabiting both roots and aerial tissues. The bacteria isolated from seeds were Pseudomonas fluorescens and Pseudomonas sp., which indicates that seeds function, not only as carriers of genetic information, but also as carriers of symbiotic-like or other bacteria between generations.

Seventy-five percent of the isolates from the in vitro-grown strawberry were identified as Pantoea spp. by API 20E. By ERIC-PCR, most of these isolates were shown to form a group that was later named group A. The grouping was made on the basis of a uniform amplification product that resembled the strongly amplified fragments of Pantoea agglomerans (HAMBI
1899) and Erwinia carotovora (HAMBI 1429) (Fig. 1). In in vitro-grown strawberries Pantoea was found in 27 cases of 36 isolates, and 21 of them belonged to Pantoea group A. For all field-grown garden strawberries, and wild strawberries Pantoea was in 56 cases of 247 isolates and 6 cases of the 52 isolates respectively, but for these plant types there were observed only single isolates of Pantoea group A bacteria.

Pseudomonas species, identified as Pseudomonas aeruginosa, P. fluorescens/putida or Pseudomonas sp. by API 20 E, were present in all plant tissue types, except berries. In ERICPCR, similarities, but not completely matching band patterns, were found with the reference strains P. fluorescens (HAMBI 2167), P. putida (HAMBI 17), $P$. aeruginosa (HAMBI 25), $P$. fragi (HAMBI 28), P. syringae pv. syringae (HAMBI 1436), P. syringae pv. phaseolicola
(HAMBI 1435), and P. chlororaphis (HAMBI 1977). Some subgroups of Pseudomonas species, originating from stolon, leaf stalk, leaf, flower and root, were found to fluoresce at $365 \mathrm{~nm}$.

By means of in situ hybridization with the eubacterial probe EUB338, endophytes were detected in all plant tissues tested (Fig. 2). Endophytes were detected single, in pairs or in small microcolonies, especially in parenchymal tissues of stalks (Fig. 2b and c) and stolons. There were two main types of microcolonies: strings of loosely associated cells attached to plant cell wall (Fig. 2a, thick arrows) and irregular aggregates of either small rod-shaped cells (Fig. 2a, thin arrows) or larger rounded cells. Rod-shaped bacteria attached to host cell walls were detected in the in vitro 'Jonsok' (Fig. 2d). Endophytes were also detected in 

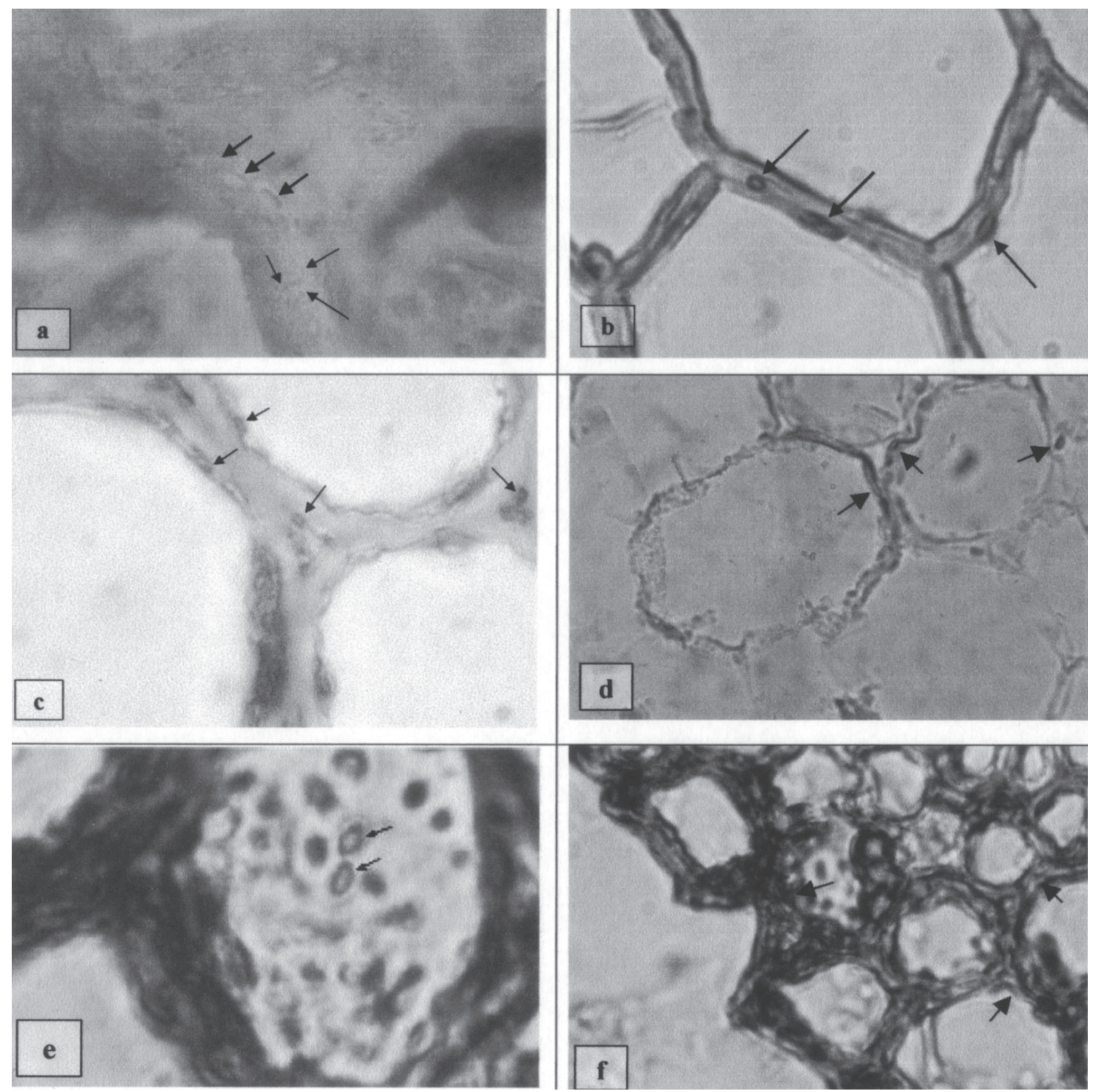

Fig. 2. In situ hybridization of strawberry (Fragaria $\times$ ananassa Duch.) with a DIG-labelled oligonucleotide probe complementary to eubacterial $16 \mathrm{~S}$ rRNA sequence. (a) A string of larger rod-shaped cells (thick arrows) is attached to the host cell wall in berry. Thin arrows point to a microcolony of smaller rods. (b) Leaf stalk parenchyma with bacteria between cells. (c) Flower stalk parenchyma. Hybridization signal was detected at cell walls and in intercellular spaces. (d) Leaf stalk parenchyma of in vitro strawberry with bacteria attached to cell walls. (e and f) Vascular tissue of in vitro seedling. Arrows point at cells presenting strong hybridization signal.

aseptically germinated seedlings (Fig. 2e and f) but the isolation of bacteria from them was not successful.

\section{Discussion}

Isolation of a completeendophytic population is problematic because of the adhesion of bacteria to plant cell structures and because surface disinfection is always a compromise between elimination of surface contaminants and survival of cortex endophytes (Hallmann et al., 1997). In addition, there can be bacteria(e.g.,phytoplasma) that are nonculturable, or population densities can be below the detection level.

In the in vitro strawberry, Gram-negative bacteria were the most frequent. This supports the results of Reed etal. (1995) who mostly found Gram-negatives as contaminants of micropropagated mint. Pantoea genus, especially Pantoea group $\mathrm{A}$, seems to be favored by in vitro culture. Conditions of in vitro culture have been reported to make plants susceptible to potential bacterial colonizers (Leifert et al., 1994). Such factors as weak plant epidermis, poorly developed stomata and open wound surfaces facilitate the entrance of bacteria into tissue, and special nutritive and physical conditions can change or favor certain types of endophytic bacterial populations (Leifert et al., 1994). However, bacteria belonging to the Pantoea genus are commonly found in endophytic habitats in leaf tissues of citrus rootstock (Araújo et al., 2001) and stems of pea (ElviraRecuenco and van Vuurde, 2000).

Because of rare contacts with humans, wild strawberry, unlike garden strawberry, was not 
expected to contain human-associated bacteria. However, human-associated bacteria, such as Gram-positive cocci, were detected in wild strawberry with about the same frequency as in field-grown garden strawberry. The main difference was that Bacillus spp. could not be identified in wild strawberry. In field-grown garden strawberry, in contrast, some identified Bacillus spp. were isolated from roots. According to Hallmann (2001), roots are an important gateway for colonization by endophytic bacteria. In the postcolonization process, however, Bacillus spp. bacteria are possibly not able to penetrate or are prevented from penetrating into vascular tissue, which is the route to aerial parts of the plant (Hallmann, 2001).

Anothermajorgroup ofbacteriawerePseudomonas species, some of which were identified as P. fluorescens. Parallel results have been obtained for artichoke, where the amount of endophytic isolates was $75 \%$ (Peñalver et al., 1994). The majorgenera in peawere Pseudomonas, Pantoea and Bacillus (Elvira-Recuenco and van Vuurde, 2000). Seeds, which are important carriers of genetic information, are generally considered free of contamination. Bacterial isolates from seeds have previously been argued not to be truly endogenous, but rather strains introduced from the environment or latent phytopathogens (Araújo et al., 2001, Mundt and Hinkle 1976). However, in our study pseudomonads were found in seeds, as well as in roots and aerial parts of the plant. Mundt and Hinkle (1976) have made similar observations in ovules and seeds of diverse species where they found Bacillus, Erwinia, Flavobacterium and Pseudomonas. These observations support the idea that seeds function as carriers of endophytic bacteria to the next generation. Further, the presence of bacteria in tissues of aseptically germinated seedlings was confirmed by in situ hybridization.

According toHallmann(2001)andKobayashi and Palumbo (2000), the effects of endophytes to plants can be categorized into growth regulating effects and disease control. Endophytic bacteria can also prevent plant growth (Schippers et al., 1990). Sturz et al. (1999) found that the bacteria located in the innerplant tissue is able to contribute different disease resistance than the bacteria of outer tissue. They observed that disease control of antibiosis of bacteria is most effective in potato tubers in the outer layers, while the bacteria found in the inner layers have weaker effects. In silver birch(Betulapendula), Pseudomonasfluorescens was found to be a promising biocontrol agent for seedling nurseries (Björklöf et al., 2002).

In this study, endophytic bacterial populations of garden strawberry and wild strawberry were investigated. A Pantoea spp. group A was predominant in the in vitro strawberry, butrarely detected in field-grown strawberry. Pseudomonas species, Pseudomonas fluorescens in particular, were found widely distributed in different strawberry tissues.

\section{Literature Cited}

Amann, R.I., J. Stromley, R. Devereux, R. Key, and D.A. Stahl. 1992. Molecular and microscopic identification of sulfate-reducing bacteria in multispecies biofilms. Appl. Environ. Microbiol. 58:614-623.

Araújo, W.L., W. Maccheroni, Jr., C.I. Aguilar-Vildoso,
P.A.V. Barroso, H.O. Saridakis, and J.L. Azevedo. 2001. Variability and interactions between endophytic bacteria and fungi isolated from leaf tissues of citrus rootstocks. Can. J. Microbiol. 47:229-236.

Bacon, C.W. and D.M. Hinton. 1997. Isolation and culture of endophytic bacteria and fungi, p. 413-421. In: C. J. Hurst et al. (eds.). Manual of environmental microbiology. ASM Press, Wash., D.C.

Bacon, C.W., J.K. Porter, J.D. Robbins, and E.S. Luttrell. 1977. Epichloe typhina from toxic tall fescue grasses. Applied and Environ. Microbiol. 34:576-581.

Barraquio, W.L., L. Revilla, and J.K. Ladha. 1997. Isolation of endophytic diazotrophic bacteria from wetland rice. Plant Soil 194:15-24.

Berg, G., S. Kurze, A. Buchner, E.M. Wellington, and K. Smalla. 2000. Successful strategy for the selection of new strawberry-associated rhizobacteria antagonistic to Verticillium wilt. Can. J. Microbiol. 46:1128-1137.

Björklöf, K., R. Sen, and K.S. Jørgensen. 2002. Maintenance and impacts of an inoculated mer/luc-Tagged Pseudomonas fluorescens on microbial communities in birch rhizospheres developed on humus and peat. Microbial Ecol. 45:39-52.

Cameron, R.K., R.A. Dixon, and C.J. Lamb. 1994. Biologically induced systemic acquired resistance in Arabidopsis thaliana. Plant J. 5:715-725.

Chen, C., E.M. Bauske, G. Musson, R. Rodriguez-Kabana, and J.W. Kloepper. 1995. Biological control of Fusarium wilt on cotton by use of endophytic bacteria. Biological Control 5:83-91.

Davison, J. 1988. Plant beneficial bacteria (review). Biotechnology 6:282-286.

Eisel, D., S. Grünewald-Janho, P. Hloch, P. Höfner, J. Keesey, B. Kruchen, and B. Rüger(eds.). 2000. DIG application manual for filter hybridization. Roche Diagnostics GmbH, Mannheim, Germany.

Elvira-Recuenco, M. and J.W.L. van Vuurde. 2000. Natural incidence of endophytic bacteria in pea cultivars under field conditions. Can. J. Microbiol. 46:1036-1041.

Ferguson, C.M.J., N.A. Booth, and E.J.Allan. 2000. An ELISA for the detection of Bacillus subtilis L-form bacteria confirms their symbiosis in strawberry. Lett. Appl. Microbiol. 31:390-394.

Frommel, M.I., J. Nowak, and G. Lazarovits. 1991. Growth enhancement and developmental modifications of in vitro grown potato (Solanum tuberosum ssp. tuberosum) as affected by a nonfluorescent Pseudomonas sp. Plant Physiol. 96:928-936.

Guinebretiere, M.H., C. Nguyen-The, N. Morrison, M. Reich, and P. Nicot. 1999. Isolation and characterization of antagonists for the biocontrol of the postharvest wound pathogen Botrytis cinerea on strawberry fruits. J. Food Protection 63:386-394.

Hallmann, J., A. Quadt-Hallmann, W.F. Mahaffee, and J.W. Kloepper. 1997. Bacterial endophytes in agricultural crops. Can. J. Microbiol. 43:895-914.

Hallmann, J. 2001. Plant interactions with endophytic bacteria, p. 87-119. In: M.J. Jeger and N.J. Spencer (eds.). Biotic Interactions in Plant-Pathogen Associations. CAB Intl., Wallingford, Oxford, U.K.

Holland, M.A. 1997. Occam's razor applied to hormonology: are cytokinins produced by plants? Plant Physiol. 115:865-868.

King, E.O., W.K. Ward, and D.E. Raney. 1954. Two simple media for the demonstration of pyocyanin and fluorescein. J. Lab. Clin. Med. 44:301-307.

Kobayashi, D.Y. and J.D. Palumbo. 2000. Bacterial endophytes and their effects on plants and uses in agriculture, p. 199-233. In: C.W. Bacon and J.F. White, Jr. (eds.). Microbial endohytes. Marcel Dekker, Inc., New York.

Lazarovits, G. and J. Nowak. 1997. Rhizobacteria for improvement of plant growth and establishment. HortScience 32:88-192.

Leifert, C., C.E. Morris, and W.M. Waites. 1994. Ecology of microbial saprophytes and pathogens in tissue culture and field-grown plants: reasons for contamination problems in vitro. Crit. Rev. Plant Sci. 13:139-183.
Lu, J.-J., C.-L. Perng, S.-Y. Lee, and C.-C. Wan. 2000. Use of PCR with universal primers and restriction endonuclease digestions for detection and identification of common bacterial pathogens in cerebrospinal fluid. J. Clin. Microbiol. 38:2076-2080.

Mahaffee, W.F. and J.W. Kloepper. 1997. Temporal changes in the bacterial communities of soil, rhizosphere, and endorrhiza associated with field grown cucumber (Cucumis sativus L.). Microbial Ecol. 34:210-223.

Mundt, J.O. and N.F. Hinkle. 1976. Bacteria within ovules and seeds. Appl. Environ. Microbiol. 32:694-698.

Murashige, T. and F. Skoog. 1962. A revised medium for rapid growth and bioassays with tobacco tissue cultures. Physiol. Plantarum 15:473-479.

Nejad, P. and P.A. Johnson. 2000. Endophytic bacteria induce growth promotion and wilt disease suppression in oilseed rape and tomato. Biol. Control 18:208-215.

Peñalver, R., N. Durán-Vila, and M. López. 1994. Characterisation and pathogenicity of bacteria from shoot tips of the globe artichoke (Cynara scolymus L.). Ann. Appl. Biol. 125:501-513.

Pillay, V.K and J. Nowak. 1997. Inoculum density, temperature, and genotype effects on in vitro growth promotion and epiphytic and endophytic colonization of tomato (Lycopersicon esculentum $\mathrm{L}$.) seedlings inoculated with a pseudomonad bacterium. Can. J. Microbiol. 43:354-361.

Pirttilä, A.M., H. Laukkanen, H. Pospiech, R. Myllylä, and A. Hohtola. 2000. Detection of intracellular bacteria in the buds of scotch pine (Pinus sylvestris L.) by in situ hybridization. Appl. Environ. Microbiol. 66:3073-3077.

Pleban, S., L. Chernin, and I. Chet. 1997. Chitinolytic activity of an endophytic strain of Bacillus cereus. Lett. Appl. Microbiol. 25:284-288.

Reed, B.M., P.M. Buckley, and T.N. DeWilde. 1995 Detection and eradication of endophytic bacteria from micropropagated mint plants. In Vitro Cell. Dev. Biol. 31P:53-57.

Rolighed, J. and H. Lindeberg. 1996. Detection of HPV 11 DNA in paraffin-embedded laryngeal tissue with a DIG-labeled DNA probe, p. 122-125. In: S. Grünewald-Janho, J. Keesey, M. Leous, R. van Miltenburg and C. Schroeder(eds.). Nonradioactive in situ hybridization manual. $2^{\text {nd }}$ ed. Boehringer Mannheim GmbH, Biochemica, Germany.

Ruzin, S. 1999. Plant microtechnique and microscopy. Oxford Univ. Press, New York.

Samish, Z., R. Etinger-Tulczynska, and M. Bick. 1961. Microflora within healthy tomatoes. Appl. Microbiol. 9:20-25.

Schippers, B.,A.W. Bakker, and P.A.H.M. Bakker. 1990 Beneficial and deleterious effects of $\mathrm{HCN}$-producing pseudomonas on rhizosphere interactions. Plant Soil 129:75-83.

Sturz, A.V., B.R. Christie, and B.G. Matheson. 1998. Associations of bacterial endophyte populations from red clover and potato crops with potential for beneficial allelopathy. Can. J. Microbiol. 44:162-167.

Sturz, A.V., B.R. Christie, B.G. Matheson, W.J. Arsenault, and N.A. Buchanan. 1999. Endophytic bacterial communities in the periderm of potato tubers and their potential to improve resistance to soil-borne plant pathogens. Plant Pathol. 48:360-369.

Tanprasert, P. and B.M. Reed. 1997. Detection and identification of bacterial contaminants of strawberry runner explants, p. 139-143. In: A. Cassells (ed.). Pathogen and microbial contamination management in micropropagation. Kluwer Academic Publ., Netherlands.

Versalovic, J., T. Koeuth, and J. Lupski. 1991. Distribution of repetitive DNA sequences and application to fingerprinting of bacterial genomes. Nucleic Acids Res. 19:6823-6831.

Wright, S.A.I., C.H.Zumoff, L. Schneider, and S.V. Beer. 2001. Pantoea agglomerans strain EH318 produces two antibiotics that inhibit Erwinia amylovora in vitro. Appl. Environ. Microbiol. 67:284-292. 